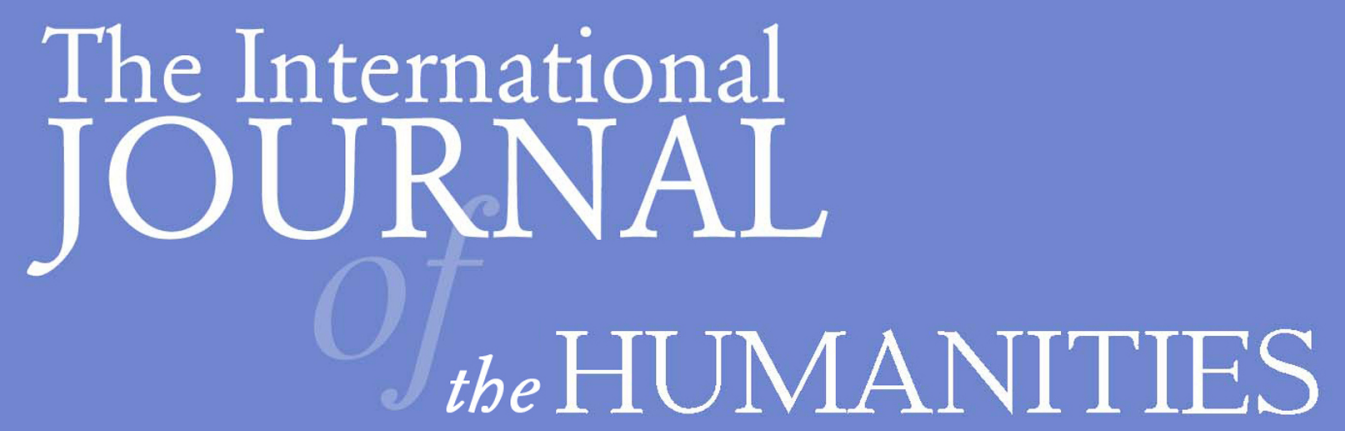

Carl Orff: Musical Humanist

Daniel C. Johnson 
INTERNATIONAL JOURNAL OF THE HUMANITIES

http://www.Humanities-Journal.com

First published in 2005/2006 in Melbourne, Australia by Common Ground Publishing Pty Ltd www.CommonGroundPublishing.com.

(C) 2005/2006 (this paper), the author(s)

(C) 2005/2006 (selection and editorial matter) Common Ground

All rights reserved. Apart from fair use for the purposes of study, research, criticism or review as permitted under the Copyright Act (Australia), no part of this work may be reproduced without written permission from the publisher. For permissions and other inquiries, please contact <cg-support@ commongroundpublishing.com>.

ISSN: 1447-9508 (print), 1447-9559 (online)

Publisher Site: http://www.Humanities-Journal.com

The INTERNATIONAL JOURNAL OF THE HUMANITIES is a peer refereed journal. Full papers submitted for publication are refereed by Associate Editors through anonymous referee processes.

Typeset in Common Ground Markup Language using CGCreator multichannel typesetting system http://www.CommonGroundSoftware.com. 


\title{
Carl Orff: Musical Humanist
}

\author{
Daniel C. Johnson, University of North Carolina Wilmington, United States of America
}

\begin{abstract}
Beyond the obvious knowledge and skills imparted, education respects and enables students in ways that training does not. Composer Carl Orff articulated a central theme of his approach to education also known as Orff-Schulwerk, or schooling in music through active involvement when he wrote: "Anyone who has worked with children or young people in the spirit of Schulwerk will have discovered that it has a humanizing influence which transcends its musical function." This paper is an exploration of the Schulwerk in terms of its humanizing potential as well as a comparason of the Schulwerk to humanism as articulated by Abraham Maslow and Carl Rogers.
\end{abstract}

Keywords: Music, Humanism, Education

\section{Introduction}

$\mathrm{B}$ EYOND THE OBVIOUS knowledge and skills imparted, education respects and enables students in ways that training does not. Composer Carl Orff articulated a central theme of his approach to education also known as Schulwerk, or schooling in music through active involvement when he wrote: "Anyone who has worked with children or young people in the spirit of Schulwerk will have discovered that it has a humanizing influence which transcends its musical function." (Orff, 1962, p. 13). Making music is a social phenomenon and learning music is fundamentally a social achievement, influenced by the sphere of human culture. Simply put, people make music and find meaning in music with other people. Music educators have realized this aspect of music-making and have studied cultural factors affecting music. In the sociology of music education, social constructivists have suggested that social experience and interaction give rise to socially mediated meaning. Humanism is an example of a psychological philosophy that supports the importance of social contexts in music education. The Orff-Schulwerk pedagogy is an example of an approach that recognizes its fundamental links to humanism.

\section{Humanism}

In humanism, the "third force" of psychology, there is no absolute determinism in matters of human behavior. Instead, humanists such as Carl Rogers (b. 1902) and Abraham Maslow (1908-1970) asserted that people freely choose the behaviors that are the most rewarding and personally satisfying. In this approach, the goal of education is to help each person reach his or her own potential. Fundamental to humanism are assumptions that all humans have the natural potential to learn and are eager to learn. Maslow suggested that for every human being there is an active will toward health, an impulse toward growth, and a natural inclination toward the actualization of human potentialities. In humanism, emphasis is placed on learning how to learn and on adaptability to changing situations, resulting in independence, creativity, and self-reliance. In other words, only an education person has learned how to learn (Rogers \& Freiberg, 1994).

In humanism, behavior is perceived holistically, including aspects of both psychoanalysis and behaviorism. The result is an understanding of human beings as functioning in accordance with a variety of unconscious internal and external forces. Learning is driven by internal forces of growth and takes place without the threat of failure. Instead, when the student sees relevance in the subject matter and explores through a process of discovery, the most lasting and pervasive learning takes place. Externally, the teacher is part of the larger group and acts as a facilitator and a guide. The teacher is an equal as a learner and provides a stable environment by valuing each individual's response, and encouraging students to take creative risks. Through self-criticism and selfevaluation, students direct their own learning using the resources and situations presented to them by the teacher.

In the work of Carl Rogers, an emphasis is paced on the student understanding his or her own feelings and redirecting those feelings in a constructive way. In this manner, the student develops self-evaluation, self-direction, and self-discovery. In opposition to Skinner's theories of behaviorism, Rogers rejected the ultimate value of operant conditioning for social control. Instead, he highlighted the value of the individual, the natural human worth of all people, and the right of the individual to determine his or her

INTERNATIONAL JOURNAL OF THE HUMANITIES, VOLUME 3, 2005/2006

http://www.Humanities-Journal.com, ISSN $1447-9508$ (print), 1447-9559 (online)

(C) Common Ground, Daniel C. Johnson, All Rights Reserved, Permissions: cg-support@commongroundpublishing.com 
own personal actions. The resulting process was an innovative approach to psychology, utilizing encounter groups and emphasizing creative self-discovery. Rogers's research has also had revolutionary applications to education.

According to Rogers, the teacher is a facilitator of learning instead of a source of all knwoledge. As such the teacher seeks to empower the students using concepcts of self-regualtion and promoting individual responsibitliy. Evidence of Rogers's influence on education include: open classrooms, student-centered curricula, teacher-pupil contracts, and a de-emphasis of schedules and competitive examinations. Although more challenging than traditional behaviorist models of schooling, Rogers's approach to education engenders positive student-teacher relationships and respects the innate desire of all students to achieve and express themselves. In effect, the dehumanizing and mechanistic approach rejected by Rogers is designed to "drill in" information into students; on the contrary, education is designed to "pull out" students' interrests and best efforts by promoting self-respect and individual responsibility. Maslow's work also impacted education in a similar fashion.

As with Rogers's research, Abraham Maslow's work was also successfully adapted to the field of education. Perhaps Maslow's words best sum up this psychological link between humanism and progressive education. In Toward a Psychology of Being (1968), Maslow wrote:

What I am really interested in is the new kind of education which we must develop which moves toward fostering the new kind of human being that we can be, the process person, the creative person, the improving person, the selftrusting, the courageous person, the autonomous person. (p. 96)

Understanding and teaching may bring not only students but also teachers to a deeper understanding of their own potentialities as musicians and as human beings. Maslow revolutionized the field of psychology in the 1960's, introducing new views on human nature counter to behaviorism and psychotherapy of the time. Maslow characterized humanism as a revolution in the oldest and truest sense of the word. He proposed a hierarchy of human needs as the motivation behind human behavior and suggested that every person could achieve self-actualization by satisfying successive levels of needs. Maslow believed that human behavior was not a function of simple stimulus/response mechanisms, contrary to the prevailing paradigm of his day. He hypothesized a series of levels, each building upon the next, the most basic being physiological needs, such as food and shelter. These formed the base of the pyramid and are a foundation without which, Maslow asser- ted, higher levels were not possible. Once the first level was satisfied, an individual could address safety needs and social needs including affection and belonging. Finally, the individual could reach esteem or ego needs including autonomy, self-actualizaion, and recognition. As a humanist, Maslow understood human behavior as a function of realizing human potential, from the most basic needs for survival to the highest levels of transcendence.

Maslow's hierarchy of human needs provided a system of five levels which address people's innate needs. From the basic psychological needs for shelter and food, the hierarchy ascends to safety and security, followed by belongingness and love, to self-esteem, and finally self-actualization. Maslow asserted that without fulfilling the needs of one level, one could not advance to the next level. As Maslow wrote, there is a drive to fulfill the highest level of self-expression as self-actualization. In other words, a musician must make music just as a poet must write, and an artist must paint. Unless and until the person is doing what he or she is best suited for, the person will not be ultimately happy. (Maslow, 1968) Music as an activity is capable of fulfilling many human needs beyond the most basic level. Through music, people can find a sense of love, safety, security, self-esteem, and self-actualization.

\section{Orff-Schulwerk}

\section{Carl Orff}

German musician Carl Orff (1895 - 1982) was first a composer and later an educator. After studying at the Academy of Music in Munich, he and Gunid Keetman founded the Günter Schüle in 1924 with a focus on simlistic musical forms to accompany dance. As a composer, Orff's work reflects his interest in primitive or elemental music. For example, his most well-known work is Carmina Burana (1937), a scenic oratorio based on a group of medieval poems sung in German and Latin. The musical material features dissonant counterpoint and energetic percussive rhythms also used in two other works forming a trilogy; Catuli Carmina (1943) is a cantata based on the works of Catullus while Trionfo di Afrodite (1953) celebrates love and includes poems by Sappho and a chorus from Euripides's Hippolytus. Orff's other well-known works include the operas Antigone (1949), Der Mond - The Moon (1939), and Die Kluge-The Wise Woman (1943). In addition to operas, Orff's interest in the synergy of music, words, and dance is evident in Orff-Schulwerk, his approach to music education.

Since its inception, Orff-Schulwerk pedagogy has provided an active and experiential model in music education. Evidence of the Schulwerk's success in- 
cludes its use in countries worldwide as well as extensions in other idioms such as jazz and multicultural musics. Promoting a synthesis of movement and music, the Schluwerk strives to encourage joyous music-making through active participation in elemental music. Experiential, conceptual and pedagogical elements converge in imitation, exploration, improvisation nd creation of music. Through movement, speech, singing, and playing instruments, the students are engaged in classroom activities. While the teacher observes, organizes, and plans the lessons, the educational environment is prepared for the students to explore. Conceptually, the Schluwerk encourages students to analyze, reflect, and critique their own work as they develop higher-order cognitive skills. By memorizing and performing music, the students build their technical skills and are intrinsically motivated to share their work.

Orff-Schluwerk encourages active music-making by all students, not just the musically talented or inclined. As Gehrkens proclaimed at the 1923 Music Supervisors National Conference, "Music for every child, every child for music.” Regardless of any student's ability level, his or her participation is facilitated by the Orff-Schulwerk process of guided experiences, followed by imitation, exploration and improvisation. Through these activities, the students learn in a progression that invites and honors their ideas and creativity. The students' development as a function of their participation in the Schluwerk has cognitive, social, emotional, and aesthetic implications beyond their understanding of music. As stated in the Rationale for the Orff-Schulwerk Learning Model:

The purpose of Orff-Schulwerk is to awaken the artistic potential in every individual and offer a context in which this can be exercised. The Orff-Schulwerk approach as a model for learning involves a much broader spectrum of artistic activity than is traditionally induced in music.[emphasis in original] $(1997$, p. vi)

The Schulwerk holistically addresses the child's overall development through a process that emulates natural play and exploration. In the Schulwerk activities, connections among the arts are formed linking music with movement, dance, speech and drama. The result is an integrated experience best described as an "elemental synthesis of the performing arts.” (p. vi)

\section{Musical Humanism}

Understanding humanism, the field of psychology which provided an alternative to behaviorism and psychoanalysis, offers insights into Orff-Schulwerk and its distinctive process of music education. The cornerstone of humanism is the notion that personality development results from a constant striving to reach one's inherent potential despite the limitations experienced (Rogers, 1980). The potential for growth comes from one's personal view of the self and the world, rather than from forces outside of one's control such as unconscious impulses and the opinions of others. By altering students' view of themselves and teaching key musical skills, educators can lead students in developing their own musical self-expression.

As in humanism, the philosophy of Orff-Schulwerk emphasizes the student's contribution to the process of education. As Rogers wrote in $A$ Way of Being (1980), the traditional mode of education in the United States is characterized by eight principles. Two principles are most pertinent to students' contribution to education in traditional schooling:

The teachers are the possessors of knowledge, the students the expected recipients. The teachers are the experts; they know their fields. The students sit with poised pencil and notebook, waiting for the words of wisdom. There is a great difference in the stauts level between the instructors and the students.

The teachers are the possessors of power, the students the ones who obey. (Administratos are also possessors of power, and both teachers and students re the ones who obey.) Control is always exercised downward. [Italics in original.] (p. 295)

As articulated above, Rogers highlights the power differential between students and teachers in a traditional approach to education. Rogers also based his criticisms on a lack of trust shown by teachers and administrators. In other words, instead of making choices and decisions, students are required to follow a given curriculum regardless of how well it fits. Instead of discovering for themselves and learning from mistakes, students are shown what to learn and told what to think. Rogers's criticism highlights the lack of interaction between the learner and the curriculum. As Maslow noted, if the only tool you have is a hammer, it is tempting to treat everything like a nail. Instead, Orff-Schulwerk draws its foundation from teacher-directed, mutually collaborative interactions between the instructor and the students, based on freedom of ideas and celebrating creative expressions.

Particularly relevant to humanism are the social goals promoted by Orff-Schulwerk process. Activities in the Schluwerk highlight the need for cooperation and mutual respect as well as leadership and creative problem solving. As stated in part of the "Rationale for the Orff Schluwerk Learning Model," 
Orff Schluwerk is a group model, requiring the cooperative interaction of everyone involved, including the instructor. It is important that artistic development occurs within a satisfying and supportive human environment. Tolerance, helpfulness, patience, and other cooperative attitudes must be cultivated consciously. The ensemble setting requires sensitivity to the total group and awareness of the role of each individual within it. (p. v)

By establishing a context for artistic expression, the Schulwerk is able to access the artistic potential of every student at his/her own level. The emphasis in this approach is on participation by all, instead of on virtuosity attained by a few.

The characteristic pentatonic sound of the Schulwerk is also related to its humanistic character. In other words, the main purpose of Schulwerk is to help students find and form a musical expression of their own. Providing a means to honor each student's self-expression is further evidence of Orff's link to humanism. The emphasis of "sound before sight" in music highlights the importance of the musical experience in the Schulwerk. In the same way, Maslow advocated a return from conceptual to experiential learning and advocated for the inherent power of experience as a way to recover the meaning of life (1971). A comparison of Maslow's Hierarchy of
Needs (1970) and the Orff-Schulwerk process of education is shown below:

$$
\begin{aligned}
& \text { Maslow's Hierarchy of Needs: } \\
& \text { Survival--> Safety---> Understanding--> Belong- } \\
& \text { ing--> Self Esteem }
\end{aligned}
$$

The Orff-Schulwerk Process of Education:

Observation-->Imitation--> Exploration-->Improvisation--> Creation

As shown, each level of both approaches has a similar essence and forms the basis for the next successive level. After students first observe in the Orff approach, they gradually take a more active role in the class by participating in rote learning. Later stages include experimentation with the given musical material, yielding to new musical iterations and finally original pieces. Similarly, Maslow's hierarchy begins with meeting basic needs such as paying attention and following an example by rote. Safety and security are addressed as the students echo given musical material as a group. Later, students develop their own understanding while expressing themselves musically through experimentation and improvisation. Finally, self esteem is addressed as students refine, perform, and share their own musical creations. For clarity, these two approaches are compared in Table 1 below:

Table 1: A Comparison of Maslow's Hierarchy and the Orff-Schuwlerk Process of Education

\begin{tabular}{|l|l|l|}
\hline $\begin{array}{l}\text { Maslow's Hierarcy of } \\
\text { Needs }\end{array}$ & $\begin{array}{l}\text { Orff-Schulwerk Process of } \\
\text { Education }\end{array}$ & Comparison \\
\hline Survival & Observation & Meeting basic needs while being passively involved \\
\hline Safety & Imitation & Learning by rote and enjoying the safety of the group \\
\hline Understanding & Exploration & $\begin{array}{l}\text { Developing personally-relevant understanding by ex- } \\
\text { perimentation }\end{array}$ \\
\hline Belonging & Improvisation & $\begin{array}{l}\text { Expressing individual thoughts and relating those to } \\
\text { others }\end{array}$ \\
\hline Self Esteem & Creation & $\begin{array}{l}\text { Articulating and refining unique self-expressions to } \\
\text { approach self-actualization }\end{array}$ \\
\hline
\end{tabular}

Another comparative perspective on hierarchies illustrates aesthetics and information with Maslow's Hierarchy of Needs. While aesthetics are instrinsic to musicians (and other artists), information is essen- tial to education and students, and Maslow's needs are fundamental to human beings is shown in Table 2 below: 
Table 2: A Comparison of Three Hierarchies: Aesthetics, Information, and Needs

\begin{tabular}{|l|l|l|}
\hline Hierarchy of Aesthetics & Hierarchy of Information & Hierarchy of Needs \\
\hline (as a musician) & (as a student) & (as a person) \\
\hline Perceiving and Reacting & Coping & Survival \\
\hline Producing & Helping & Safety \\
\hline Conceptualizing & Educating & Understanding \\
\hline Evaluating and Analyzing & Enlightening & Belonging \\
\hline Valuing & Empowering & Self Esteem \\
\hline
\end{tabular}

\section{Conclusion}

In conclusion, the approach to music education designed by Carl Orff may at first seem to consist of specifically musical terminology and concepts. By framing this approach in terms of a broader humanistic and social context, however, both teachers and students may better appreciate its potential and humanizing effect. Similarly, by understanding humanism and the importance social factors play in music teaching and learning, researchers amd educators may better comprehend the Schluwerk in psychological terms and value its humanizing influence on students. Including benefits to students beyond specifically musical growth, educators may expand the musical possibilities afforded to their students for the rest of their lives.
To promote authentic self-expression and success for students in musical settings, educators frequently adopt the Orff-Schulwerk approach to music educaiton. Following the appraoch and doing the activites, however, may not be sufficient to fully realize the potential benefits of this approach. Instead, educators need to understand the social and humanizing facets of the Schulwerk to appreciate and take full advantage of this approach. Problem-solving, social growth, critical thinking, and self-expression are all natural extensions of Schulwerk made possible by an informed and thorough understanding of the Schulwerk. Further research and study is necessary to investigate other applications and transferance to additioanl subjects and arenas in students' lives.

\section{References}

American Orff-Schulwerk Association. (1977). Guidelines for Teacher-Training Courses. Cleveland Heights, OH: American Orff Schulwerk Association.

Maslow, A. (1968). Toward a Psychology of Being. New York, NY: Van Nostrand Rienhold.

Maslow, A. (1970). A Theory of Human Motivation. In A. Maslow (Ed.), Motivation and Personality. New York, NY: Harper and Row.

Maslow, A. (1971). The Farther Reaches of Human Nature. New York, NY: Viking Press.

Orff, C. (1962). In Orff Re-Echoes Vol. 2, Ed. Carley, I. Cleveland Heights, OH: American Orff Schulwerk Association. Rogers, C. (1980). A Way of Being. Boston, MA: Houghton Mifflin.

Rogers, C., \& Freiberg, H. J. (1994). Freedom to Learn, (Third Edition). New York, NY: Macmillian College Publishing Company.

\section{About the Author}

\section{Dr. Daniel C. Johnson}

Daniel C. Johnson, Ph.D., is the Assistant Department Chair and an Assistant Professor of Music at the University of North Carolina in Wilmington. A graduate of the University of Arizona, the New England of Music, the St. Louis Conservatory of Music, and Emory University, Dr Johnson has researched music cognition, critical thinking, music listening, and educational psychology. He is a certified Orff-Schulwerk instructor and a multiinstrumentalist with over fifteen years of teaching experience. Dr Johnson has presented his research at state, regional, national, and international conferences hosted by: the Music Educators National Conference, the International Society for Music Education, the College Music Society, the American Orff-Schulwerk Association, the National Collegiate Honors Council, and numerous state music education associations. He has published articles in: The Bulletin of the Council for Research in Music Education, Contributions to Music Education, The International Journal of the Humanities, The International Tuba and Euphonium Association Journal, The Kindermusik Educators Journal, The Australian Band and Orchestra Directors Association Journal, The 
INTERNATIONAL JOURNAL OF THE HUMANITIES, VOLUME 3

Queensland Kodály News, and on-line at Musicstaff.com. The second edition of his textbook, Musical Explorations: Fundamentals Through Experience, is published by Kendall-Hunt. 
THE INTERNATIONAL JOURNAL OF THE HUMANITIES

EDITORS

Tom Nairn, RMIT University, Melbourne.

Mary Kalantzis, RMIT University, Australia.

EDITORIAL ADVISORY BOARD

Fethi Mansouri, Deakin University, Melbourne, Australia.

Paul James, RMIT University, Australia.

Juliet Mitchell, Cambridge University, UK.

Siva Vaidhyanathan, New York University, USA.

Patrick Baert, Cambridge University, UK.

Ted Honderich, University College, London.

Krishan Kumar, University of Virginia, USA.

David Christian, San Diego State University, California, USA.

Giorgos Tsiakalos, Aristotle University of Thessaloniki, Greece.

Gayatri Chakravorty Spivak, Columbia University, USA.

Mick Dodson, Australian National University, Canberra, Australia.

Jeffrey T. Schnapp, Stanford University, USA.

Nikos Papastergiadis, University of Melbourne, Australia.

Bill Kent, Monash Centre, Prato, Italy.

Chris Ziguras, RMIT University, Australia.

Eleni Karantzola, University of the Aegean, Greece.

Bill Cope, Common Ground, Australia.

ASSOCIATE EDITORS, 2005

Visit: http://www.Humanities-Journal.com

SCOPE AND CONCERNS

Visit: http://www.Humanities-Journal.com

SUBMISSION GUIDELINES

Visit: http://www.Humanities-Journal.com

INQUIRIES

Email: cg-support@commongroundpublishing.com 